\title{
Clinical Implications of Accurate Subtyping of Pituitary Adenomas: Perspectives from the Treating Physician
}

\author{
Karen GOMEZ-HERNANDEZ ${ }^{1}$, Shereen EZZAT'1, Sylvia L. ASA², Özgür METE \\ Department of 'Medicine and ${ }^{2}$ Pathology, University Health Network, University of Toronto, TORONTO, ONTARIO, CANADA
}

\begin{abstract}
Pituitary adenomas comprise a heterogenous group of adenohypophyseal tumours with distinct clinicopathological features across both the clinically functioning and silent groups. Although, predicting a clinically aggressive course remains challenging, accurate subtyping of pituitary adenomas offers valuable prognostic information that together with other clinical and radiological information serves as a platform for tailored treatment and follow-up. For instance, silent subtype 3 pituitary adenomas, silent corticotroph adenomas, acidophil stem cell adenomas, Crooke cell adenomas, and sparsely granulated somatotroph adenomas show more invasive growth. This review has been formulated as a set of practical questions that address the distinct clinical behaviour of a selected group of pituitary adenoma subtypes.
\end{abstract}

Key Words: Pituitary adenoma, Acromegaly, Hyperthyroidism, Cushing syndrome

\section{INTRODUCTION}

As members of the multidisciplinary endocrine oncology team providing care for patients with pituitary disease we have often been intrigued by the relative scarcity of studies in the field that describe the clinical relevance of accurate pituitary adenoma subtyping. Certainly, in other fields of endocrine oncology such as thyroid cancer, the description of clinicopathological features has emerged as pivotal elements in disease risk stratification and management. Although ancillary tests that distinguish aggressive pituitary adenomas from pituitary carcinomas are still unavailable, the accurate subtyping of pituitary adenomas in association with selected biomarkers is still considered the best predictor and prognosticator (1-5). Modern approaches to the classification of pituitary adenomas use a panel approach by integrating adenohypophyseal celllineage specific transcription factors (Pit-1, Tpit, SF-1, and ER), monoclonal antibodies against adenohypophyseal hormones (Growth hormone: GH, Prolactin: PRL, betathyroid stimulating hormone: beta-TSH, beta-follicle stimulating hormone: beta-FSH, beta-luteinizing hormone: beta-LH, Adrenocorticotropic hormone: ACTH, and alpha-subunit), low molecular weight keratin (CAM5.2 or cytokeratin 18), and Ki-67 (MIB-1) (1-3,5,6). p53 immunohistochemistry is also a part of this panel in some practices (5). This approach identifies tumours that are more frequently associated with invasive growth (Hardys' grade III/IV and Knosp's grade III/IV), higher recurrent rates, and

(Turk Patoloji Derg 2015, 31(Suppl):4-17)

Received : 09.06.2015 Accepted : 10.06.2015 a distinct response to therapy (Table 1). Importantly, this morphologic categorization into aggressive subtypes has been suggested to be complementary and in some instances perhaps even superior to the designation of atypical pituitary adenomas, which are invasive adenomas showing p53 positivity and/or a MIB-1 labeling index $>3 \%$. In this brief review that has been formulated as a set of questions we will address the distinct behaviour of a selected group of pituitary adenoma subtypes in selected clinical settings.

\section{A. CLINICALLY NON-FUNCTIONING PITUITARY ADENOMAS}

Question for the Pathologist: Which type of adenoma is it?

Clinical Relevance: Certain clinically non-functioning pituitary adenomas are characterized by more aggressive behaviour.

Although all pituitary adenoma subtypes can potentially present as clinically non-functioning, based on recent surgical series, gonadotroph adenomas are the most frequent (7). Amongst the less common pituitary adenomas that may present as clinically silent tumours, silent corticotroph adenomas and silent subtype 3 adenomas have more aggressive clinical behaviour in terms of size, invasive growth, and recurrence rates $(7,8)$. These tumour subtypes also present at an earlier mean age than gonadotroph adenomas (7,8). Null cell adenomas have also been recognized as more invasive than gonadotroph adenomas
Correspondence: Özgür METE

200 Elizabeth Street, 11th Floor, Department of Pathology,

University Health Network, TORONTO, ON, CANADA

E-mail: ozgur.mete2@uhn.ca Phone: +1 4163403004 


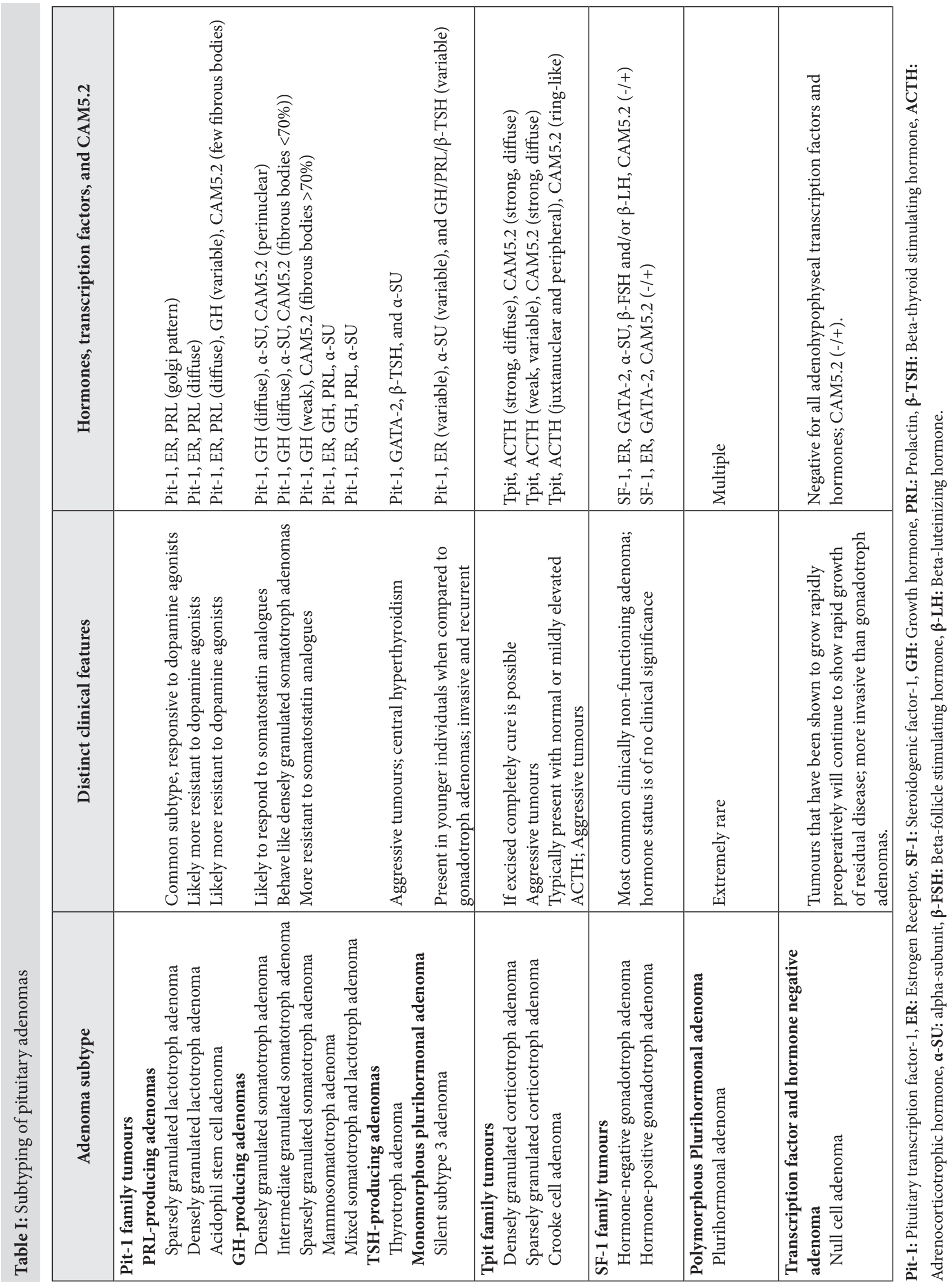


(9) and to rapidly grow after surgery if they had shown a rapid pattern of growth preoperatively (10).

\section{Null Cell Adenomas}

The appropriate classification of an adenohypophyseal tumour into the null cell pituitary adenoma category requires negativity of cell-type specific differentiation using adenohypophyseal hormones and pituitary transcription factors. The reason this type of adenoma was overrepresented in older surgical series is that without the use of pituitary transcription factors, a significant proportion of gonadotroph adenomas, which were negative for beta-FSH and beta-LH, were mistakenly subtyped as "null cell adenomas". In fact, the use of SF-1 and ER has improved the detection of gonadotroph differentiation in hormone-negative pituitary adenomas (Figure 1A,B). The distinction of null cell adenoma is of clinical relevance. Firstly, true null cell adenomas that grow rapidly before surgery will continue to show rapid growth of residual or recurrent disease postoperatively (10), a feature that dictates a close surveillance strategy. Secondly, null cell adenomas also seem to show more cavernous sinus invasion than gonadotroph adenomas (7) which as expected predicts residual disease (10).

\section{Silent Corticotroph Adenomas}

Clinically, silent corticotroph adenomas are characterized by the lack of clinical signs or symptoms of Cushing's syndrome and normal cortisol and ACTH levels $(11,12)$. These tumors often present as macroadenomas (Figure 2A) associated with mass effects (13), invasion (7), and a high frequency of pituitary apoplexy (acute hemorrhagic necrosis) (12, $14,15)$. In a study that directly compared gonadotroph adenomas (defined based on immunoreactivity for betaFSH, beta-LH or alpha-subunit) to SCA, it was shown that SCA have higher and earlier recurrences (13). Also, when compared to other clinically silent adenomas (mainly null cell adenomas and gonadotrophs adenomas), patients younger than 30 years of age with silent corticotroph adenomas more often have multiple recurrences $(>2)$ and late recurrences (more than five years after initial resection) (15). It has been suggested that interactions between tumour cells and extracellular matrix may be one of the mechanisms leading to distinct behaviour by these pituitary adenomas; it may be that osteopontin plays a role in the invasiveness of SCAs, whereas MMP-1 is more frequently expressed in gonadotroph adenomas (16).

The morphologic distinction of corticotroph origin in a non-functioning pituitary adenoma is not sufficient to complete a diagnosis, since corticotroph adenomas are a heterogeneous group of neoplasms. Densely granulated corticotroph adenomas typically present with a basophilic cytoplasm correlating with diffuse strong PAS positivity and immunoreactivity for ACTH (Figure 2B); in contrast, sparsely granulated corticotroph adenomas display focal PAS staining and weak positivity for ACTH $(1-3,17,18)$. Regardless of PAS and/or ACTH positivity, both types of corticotroph adenoma are diffusely positive for Tpit $(1,3,5,17,18)$. Silent densely and sparsely granulated
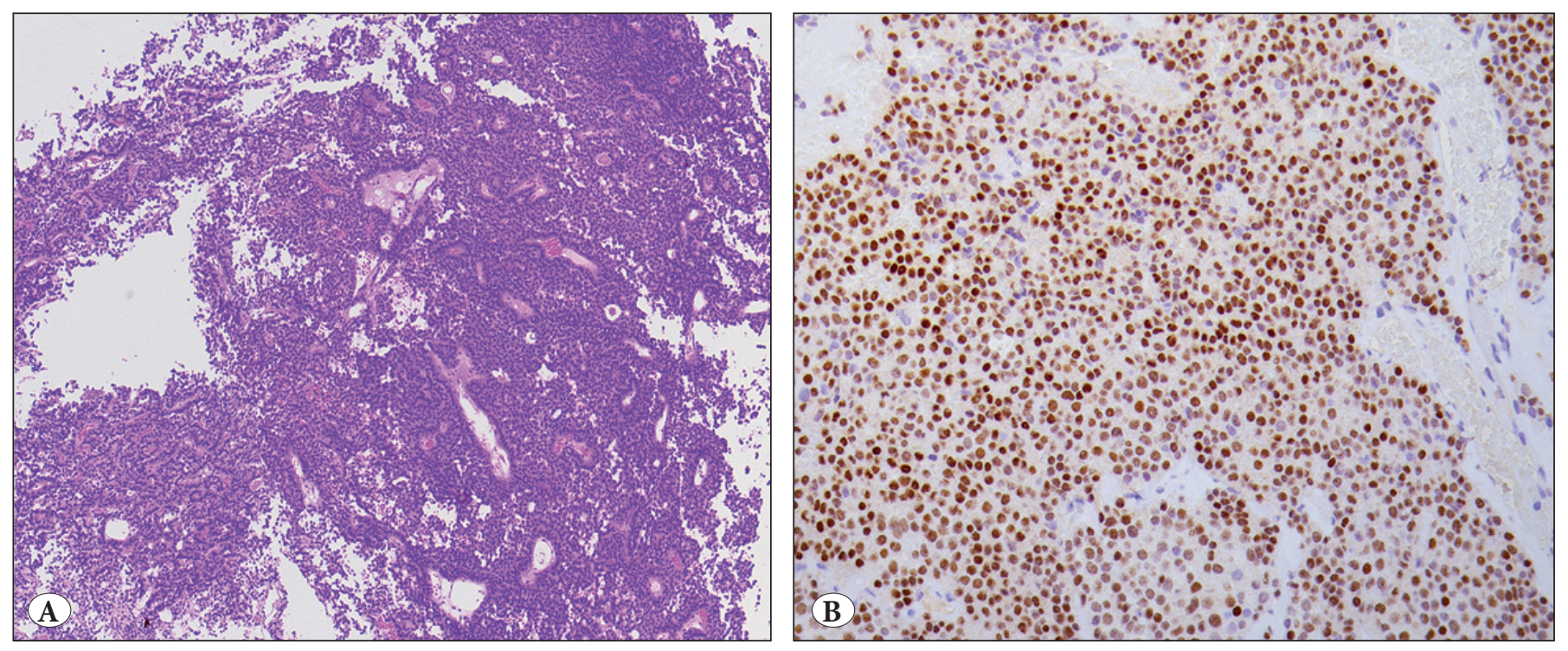

Figure 1: SF-1 immunohistochemistry helps to distinguish gonadotroph differentiation in hormone negative adenomas. A) This photomicrograph illustrates a pituitary adenoma that was negative for all adenohypophyseal hormones. B) Positivity for SF-1 confirms gonadotroph cell differentiation in this tumor. 
corticotroph adenomas are classified as type 1 (Figure 2A) and type 2 SCAs, respectively. It has been shown that type 2 SCAs have a higher expression profile of factors regulating tumor cell invasion/ migration and proliferation, such as MMP-1, $\beta 1$-integrin, and FGFR4, compared with type I SCAs ${ }^{16}$. Corticotroph adenomas with Crooke's hyaline change, also known as "Crooke cell adenomas", have also been associated with aggressive behaviour $(19,20)$.

\section{Silent Subtype 3 Pituitary Adenomas}

Silent subtype 3 pituitary adenomas are monomorphous plurihormonal Pit-1 lineage adenomas that may be clinically silent $(3,5)$. However, the term "silent" is a misnomer, since these tumours can cause acromegaly, hyperprolactinemia (albeit generally due to stalk effect) or hyperthyroidism $(8,21-23)$. These tumours tend to be invasive macroadenomas or giant adenomas (Figure 3A) and they present at an earlier mean age than gonadotroph adenonomas $(7,8,22,23)$. Also, recurrence and tumourfree status may be as low as a third of treated patients (8). Not surprisingly, radiotherapy is required in a substantial number of cases (8) and it appears to achieve control of disease (22). Somatostatin receptor expression has been shown in some of these tumours and tumour stability on long acting octreotide has been previously reported in two individuals with residual disease (22).

Pathologists should distinguish these neoplasms by demonstrating variable positivity for one or more Pit1-lineage hormones (GH, PRL, and beta-TSH) together with diffuse Pit-1 nuclear reactivity (Figure 3B-D) $(3,5)$. It is important to distinguish true tumor cell hormone expression from scattered positivity that represents entrapped nontumorous adenohypophyseal cells. Ultrastructural examination of silent subtype 3 adenomas reveals characteristic nuclear inclusions known as "spheridia" $(3,5,22)$.

\section{B. ADENOMAS CAUSING PROLACTIN EXCESS}

Question for the Pathologist: Is it a sparsely granulated lactotroph adenoma (most common subtype) or a less frequent and potentially more aggressive subtype?

Clinical Relevance: Sparsely granulated lactotroph adenomas usually respond to dopamine agonist therapy. In patients with acidophil stem cell adenomas, the diagnosis of GH excess may be missed due to a clinical picture that is dominated by symptoms related to prolactin excess.

Most "prolactinomas" are sparsely granulated lactotroph adenomas; densely granulated lactotroph adenomas and acidophil stem cell adenomas are rare (3). While acidophil stem cell adenomas are typically associated with prolactin excess, concomitant GH-excess may occur causing acromegaly or gigantism (24-26). Given the predominance of hyperprolactinemia related symptoms, the diagnosis of $\mathrm{GH}$-excess may be missed if the GH axis is not appropriately evaluated; this has been described as "fugitive acromegaly".

Hyperprolactinemia in the setting of acidophil stem cell adenomas is different from that observed in sparsely
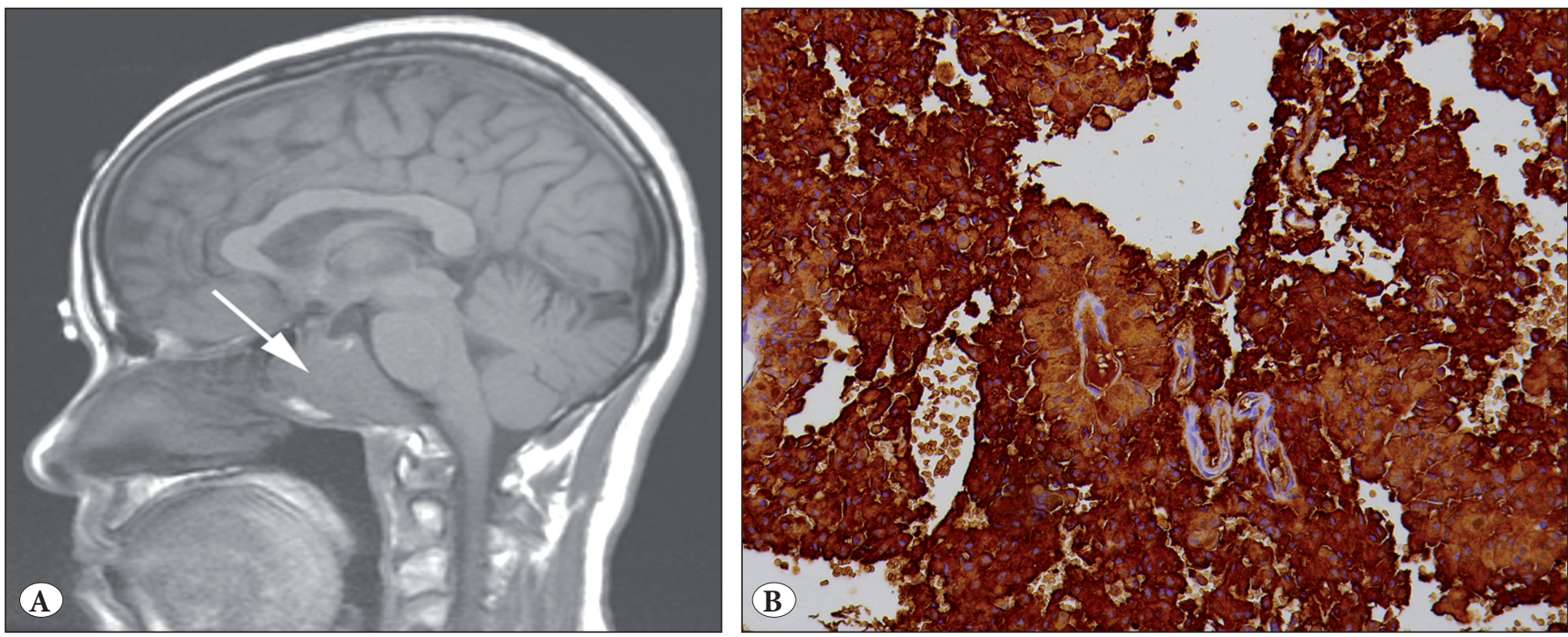

Figure 2: Silent corticotroph adenoma. A) Magnetic resonance image showing invasive growth of a silent subtype 2 adenoma; most silent corticotroph adenomas are invasive macroadenomas (arrow) with a predilection of cavernous sinus invasion, B) Diffuse ACTH expression in a type 1 silent corticotroph adenoma (densely granulated corticotroph adenoma lacking any biochemical or clinical evidence of excess ACTH) is illustrated. 


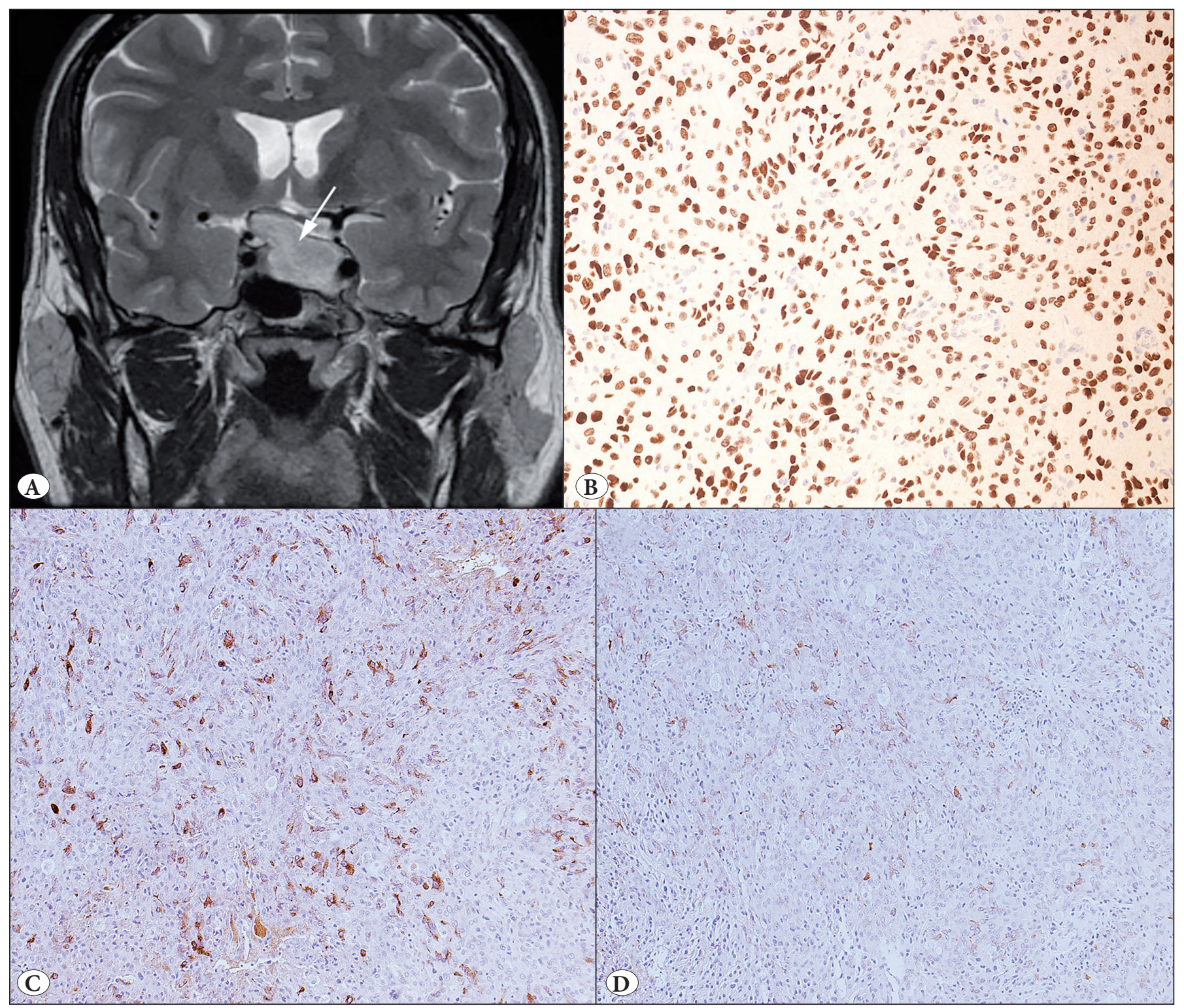

Figure 3: Magnetic resonance image and histopathology of a silent subtype 3 adenoma. A) The magnetic resonance image shows a macroadenoma with suprasellar extension and invasion into the left cavernous sinus; this patient had presented with hypopituitarism and visual field disturbances. B) Silent subtype 3 adenomas are diffusely positive for Pit-1. C-D) Variable positivity for GH, PRL, and beta-TSH render the diagnosis of these tumours (GH: C; PRL: D).

granulated lactotroph adenomas in that is not as proportional to tumour size, i.e., larger acidophil stem cell adenomas produce less prolactin than similar size sparsely granulated lactotroph adenomas. Another distinct characteristic of acidophil stem cell adenomas is that they are usually invasive macroadenomas $(27,29)$.

Although the vast majority of "prolactinomas" show a good response to dopamine agonist therapy (30); there are instances in which a reduction in tumour size and prolactin concentrations is difficult to achieve. Studies that have aimed at characterizing the relevant clinical features that are correlated with lack of therapeutic responsiveness have not provided a detailed morphologic characterization of the prolactin-producing adenomas and have instead classified them according to size, i.e., macroprolactinomas vs microprolactinomas $(31,32)$. In our own experience and as illustrated by the previous report of two pediatric cases (33), acidophil stem cell adenomas tend to be resistant to dopamine agonist therapy both in terms of prolactin reduction and tumour shrinkage. This clinical observation is supported by in vitro studies showing bromocriptine resistance in cells of acidophil stem cell adenomas (34). 
It has also been our experience that densely granulated lactotroph adenomas are relatively rare; they are usually larger and more invasive than sparsely granulated lactotroph adenomas.

From a pathological perspective, paranuclear Golgi-type PRL staining distinguishes sparsely granulated lactotroph adenomas from acidophil stem cell adenomas and densely granulated lactotroph adenomas, which often display diffuse cytoplasmic PRL expression $(3,5)$. Oncocytic change with dilated mitochondria is one of the characteristics of acidophil stem cell adenomas in addition to scattered fibrous bodies and concomitant focal GH expression $(3,5,35)$.

When compared to controls, MEN-1 patients more frequently harbour plurihormonal pituitary adenomas as well as multiple adenomas (36). Plurihormonality in this setting most often includes GH and PRL expression. On the other hand, when multiple synchronous adenomas are present they are frequently a combination of PRL- and ACTH-producing adenomas. PRL-producing tumours in MEN-1 also tend to be larger (37) and more prone to be resistant to dopamine agonists $(37,38)$.

\section{ADENOMAS CAUSING GROWTH HORMONE EXCESS}

C1. Question for the Pathologist: Is the somatotroph adenoma sparsely granulated or densely granulated?

Clinical Relevance: Differential therapeutic responsiveness to somatostatin analogues and clinical behaviour.

Pure (isolated) GH-producing pituitary adenomas are histologically classified into densely granulated and sparsely granulated somatotroph adenomas. Densely granulated somatotroph adenomas are the most frequent subtype and they generally respond better to somatostatin analogues (39-42). Part of the explanation for the differential response is that sparsely granulated somatotroph adenomas tend to be larger and more invasive (42-45) (Figure 4A) while also showing relatively lower SSTR2 expression $(46,47)$. Also, albeit discordant reports in the literature (41,47-49), it appears that a higher proportion of densely granulated somatotroph adenomas have high intracellular cAMP levels due to activation of the protein kinase-A pathway making them excellent targets for cAMP suppression via SSTR, whereas the mechanisms underlying sparsely granulated somatotroph adenomas appear to involve the STAT signaling pathway ${ }^{2,3}$. Interestingly, affected individuals with familial isolated somatotroph adenomas (some of which harbour germline mutations in the aryl hydrocarbon receptor interacting gene) tend to have invasive adenomas with less response to somatostatin analogues $(50,51)$. Not surprisingly, the proportion of sparsely granulated somatotroph adenoma is overrepresented in this syndrome $(50,51)$. It also appears that sparsely granulated somatotroph adenomas are overrepresented in the subgroup of sporadic somatotroph adenomas associated with low aryl hydrocarbon receptor interacting protein expression and poor response to somatostatin analogue therapy (52).

Pathologists distinguish these two neoplasms by assessing the staining characteristics of low molecular weight keratin (CAM5.2 or CK18), GH, and alpha-subunit (Figure 4B-D). Sparsely granulated somatotroph adenomas typically show focal or weak GH expression, no alpha-subunit expression, and prominent ( $>70 \%$ of the tumor cells) juxtanuclear globular reactivity for low molecular weight keratin, corresponding to intermediate filament aggresomes known as "fibrous bodies" $(3,5,44)$. Unlike sparsely granulated somatotroph adenomas, densely granulated somatotroph adenomas display diffuse and strong positivity for $\mathrm{GH}$ and alpha-subunit, and low molecular weight keratin stains in a perinuclear pattern $(3,5)$. Scattered fibrous bodies can be identified in some cases within the phenotype of densely granulated somatotroph adenomas; while these neoplasms are considered to represent an intermediate form of somatotroph adenoma, their biologic features including treatment response to somatostatin do not differ from densely granulated somatotroph adenomas (44).

C2. Questions for the Pathologist: Is the adenoma not a pure somatotroph adenoma? Is there any evidence of underlying somatotroph hyperplasia or multifocal disease?

Clinical Relevance: Other pituitary adenomas can also cause excess GH in addition to other hormones, mainly prolactin. The coexistence of multicentric disease and/or associated hyperplasia should alert the physician to the possibility of GHRH-producing tumors, Carney Complex or McCune Albright syndrome.

In contrast to somatotroph adenomas, mammosomatotroph adenomas $(53,54)$, mixed somatotroph and lactotroph adenomas, and other plurihormonal adenomas (silent subtype 3 adenomas, acidophil stem cell adenomas, and GH-producing plurihormonal adenomas) may cosecrete GH and PRL. Currently, it is unclear whether in acromegalic patients there is a differential response to dopamine agonist therapy between these tumours and pure somatotroph adenomas. It is important to mention though that baseline prolactin levels do not seem to predict response to dopamine agonist therapy (55). 


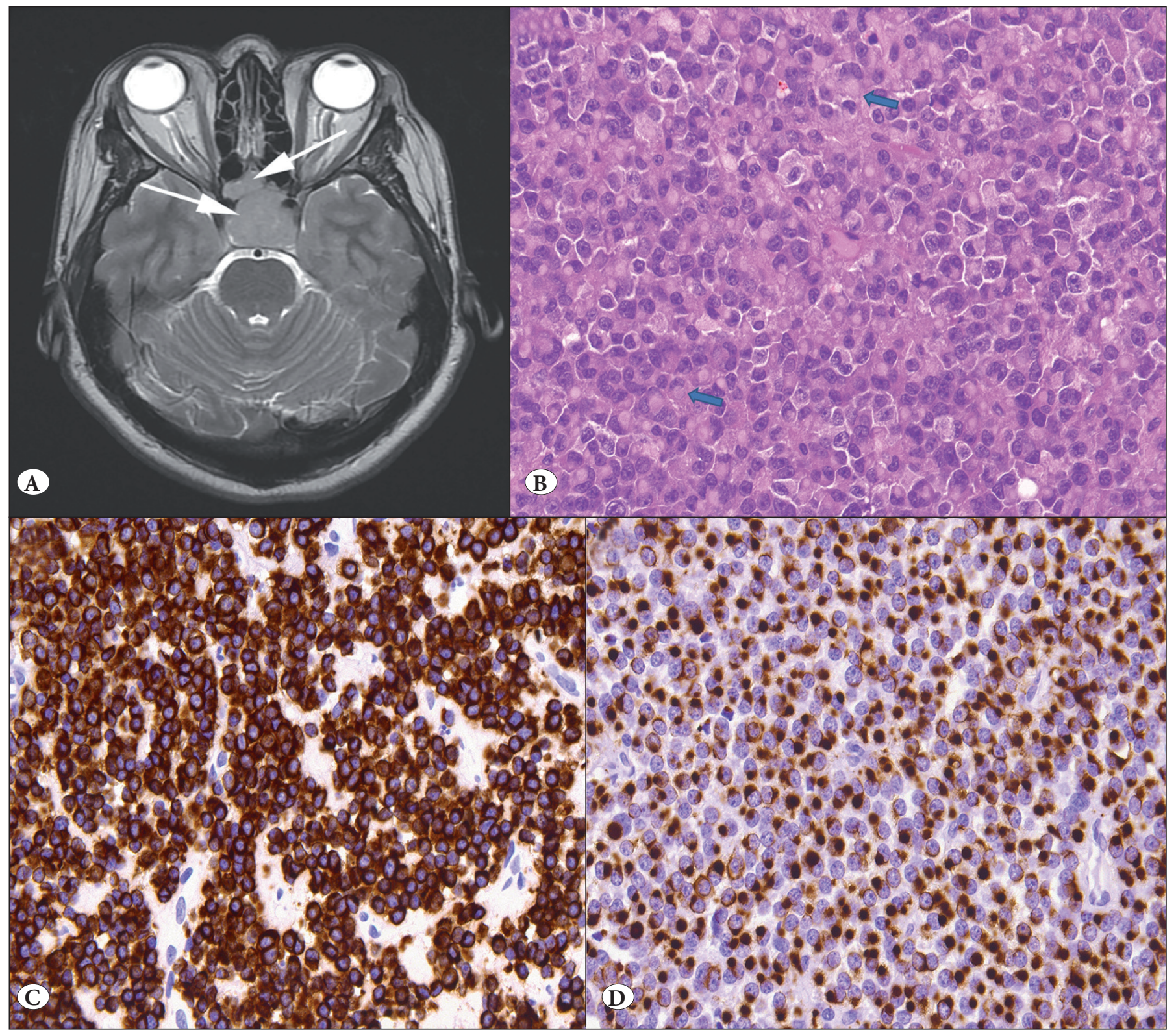

Figure 4: Sparsely granulated somatotroph adenoma. A) Magnetic resonance image showing an invasive sparsely granulated somatotroph adenoma; typically as shown here these tumours are hyperintense in T2-weighed imaging (arrows indicate the adenoma). B) Careful examination of the hematoxylin-eosin stained slides can highlight the presence of juxtanuclear globular fibrous bodies (arrows indicate fibrous bodies). $\quad$ C) Densely granulated somatotroph adenomas show diffuse alpha-subunit and perinuclear CAM5.2 expression. D) Sparsely granulated somatotroph adenomas show prominent fibrous bodies on CAM5.2.

Mammosomatotroph adenomas most commonly cause GH excess leading to acromegaly or gigantism while prolactin is usually only mildly elevated $(34,53,56,57)$. Interestingly, mammosomatotroph hyperplasia coexisting with adenomas is frequently found in patients with acromegaly in the setting of Carney complex (58-60). Precisely because of the diffuse pituitary involvement in which hyperplasia and small tumours coexist, these patients tend to have pituitary imaging that does not clearly identify the presence of an adenoma. The National Institute of Health group has been successful at treating these imaging-negative Carney complex acromegalics with somatostatin analogues (60).

The pituitaries of acromegalic patients with McCune Albright Syndrome also show areas of hyperplasia (somatotroph/mammosomatotroph) together with areas of fully developed adenoma (somatotroph/mammosomatotroph) $(61,62)$. Therefore, especially in young individuals with gigantism or acromegaly, a surgical pathology report indi- 
cating the presence of coexisting hyperplasia and adenoma should alert the clinician to the possibility of either of these multiple endocrine neoplasia syndromes.

Outside of Carney complex and McCune Albright Syndrome, very early childhood onset of pituitary gigantism ( $<4$ years old) caused by diffuse mammosomatotroph hyperplasia has been described $(63,64)$.

Finally, in some patients a combined pituitary neoplasm consisting of GHRH-producing gangliocytoma and a somatotroph adenoma can be identified in the background of somatotroph hyperplasia (65). However, the more frequent source of GHRH leading to somatotroph and/ or mammosomatotroph hyperplasia is ectopic GHRH produced by a neuroendocrine tumor of the lung, pancreas, adrenal or other sites $(66,67)$.

\section{ADENOMAS CAUSING ACTH EXCESS}

A detailed surgical pathology report is particularly relevant in the setting of Cushing disease as it provides very useful prognostic information. It may also alert the clinician as to the possibility of an incorrect diagnosis, i.e. pseudoCushing's syndrome.

D1. Questions for the Pathologist: Was an adenoma identified? Did the nontumorous corticotrophs show Crooke's hyaline change?

Clinical Relevance: Lack of identification of a corticotroph adenoma in the surgical pathology specimen is associated with non-remission after pituitary surgery. Identification of Crooke's hyaline change in the nontumorous corticotrophs confirms pathological hypercortisolemia.

Corticotroph adenomas tend to be microadenomas that sometimes can be quite small and difficult to localize. Lack of corticotroph adenoma identification in a surgical pathology specimen of a patient with Cushing disease is more frequently observed in patients in whom remission is not achieved $(68,69)$. There are several possibilities as to why an adenoma is not detected on surgical pathology: (a) it was missed by the surgeon, (b) it was destroyed during the procedure, (c) the diagnosis of Cushing disease was incorrect, (d) Cushing's syndrome was caused by corticotroph hyperplasia, but not by an adenoma.

Diffuse corticotroph hyperplasia can be due to ectopic $\mathrm{CRH}$ production (70); therefore, a surgical pathology specimen in which this type of hyperplasia is observed should prompt the clinician to initiate investigations to localize the responsible tumour. However, both diffuse and nodular forms of corticotroph hyperplasia may also be a rare aetiology of pituitary Cushing disease $(71,72)$.
The distinction between hyperplasia and adenoma is performed by assessing characteristics of the reticulin network surrounding microacinar units of the adenohypophysis. While pituitary adenoma shows loss of reticulin network, hyperplasia presents with an intact but expanded reticulin framework. Glucocorticoid excess results in Crooke's hyaline change of the non-tumorous corticotrophs (Figure 5 A,B), reflecting the negative inhibition of excess glucocorticoids on non-tumorous pituitary corticotrophs ${ }^{54,55}$. While this can easily be identified on haematoxylin and eosinstained slides, PAS along with ACTH and low molecular weight keratin can be used to highlight this cellular alteration (Figure $5 \mathrm{~A}, \mathrm{~B}$ ). Of note, Crooke's hyaline change is typically absent in diffuse corticotroph hyperplasia (due to lack of normal corticotrophs), in pseudo-Cushing syndrome, as well as in the non-tumorous corticotrophs of patients with silent corticotroph adenomas. If the specimen fails to show a corticotroph adenoma or diffuse corticotroph hyperplasia, the presence or absence of Crooke's hyaline change can provide important insights for treating physicians for the diagnosis of a pseudo-Cushing state (3).

D2. Question for the Pathologist: Which type of adenoma is it?

\section{Clinical Relevance: Distinct clinical features}

Tumours that produce ACTH can be classified as clinically non-functioning (silent subtype 1 and silent subtype 2 corticotroph adenomas reviewed above) or as clinically functioning (sparsely granulated corticotroph adenomas, densely granulated corticotroph adenomas, and Crooke cell adenomas). Amongst these adenomas causing Cushing disease, Crooke cell adenomas (Figure 6 A,B) are considered an aggressive histologic variant $(19,20)$. These tumours are usually invasive macroadenomas with a high recurrence rate that can be as high as $60 \%$ after a mean follow up of 6.7 years (20). In our experience, sparsely granulated corticotroph adenomas are also associated with more aggressive behaviour than their densely granulated counterpart.

\section{E. ADENOMAS CAUSING TSH EXCESS}

Question for the Pathologist: Is the adenoma a thyrotroph adenoma?

Clinical Relevance: Not all pituitary adenomas causing TSH excess are thyrotroph adenomas "TSHomas"; however, most adenomas leading to excess TSH are as a group aggressive tumours.

Most physicianslinkcentral hyperthyroidism to a "TSHoma". In fact, silent subtype III adenomas (monomorphous 

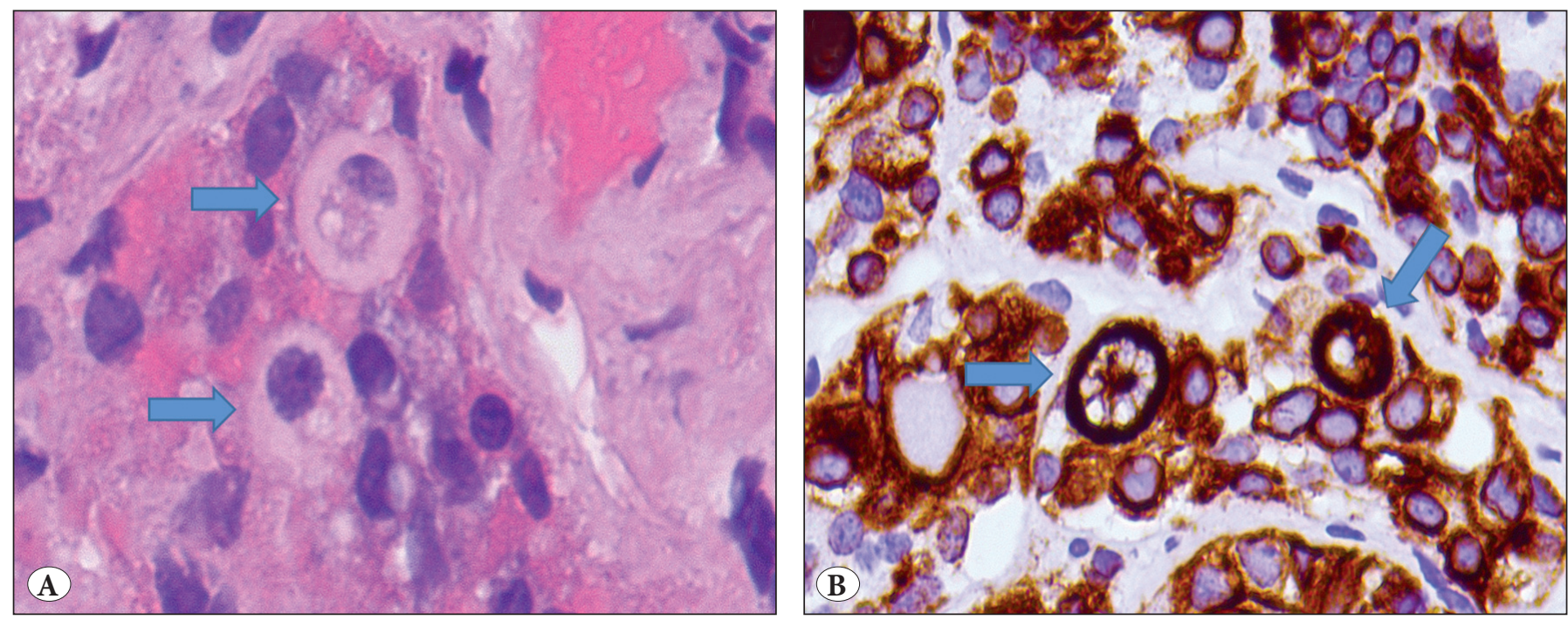

Figure 5: Crooke's hyaline change of the nontumorus corticotrophs. A) While this cellular alteration can easily be identified on haematoxylin and eosin-stained slides (arrows). B) PAS along with ACTH and low molecular weight keratin is used to highlight this finding; the translocation of ACTH containing granules to the cell membrane and juxtanuclear region is accompanied by a ring like (arrows) low molecular weight keratin expression.
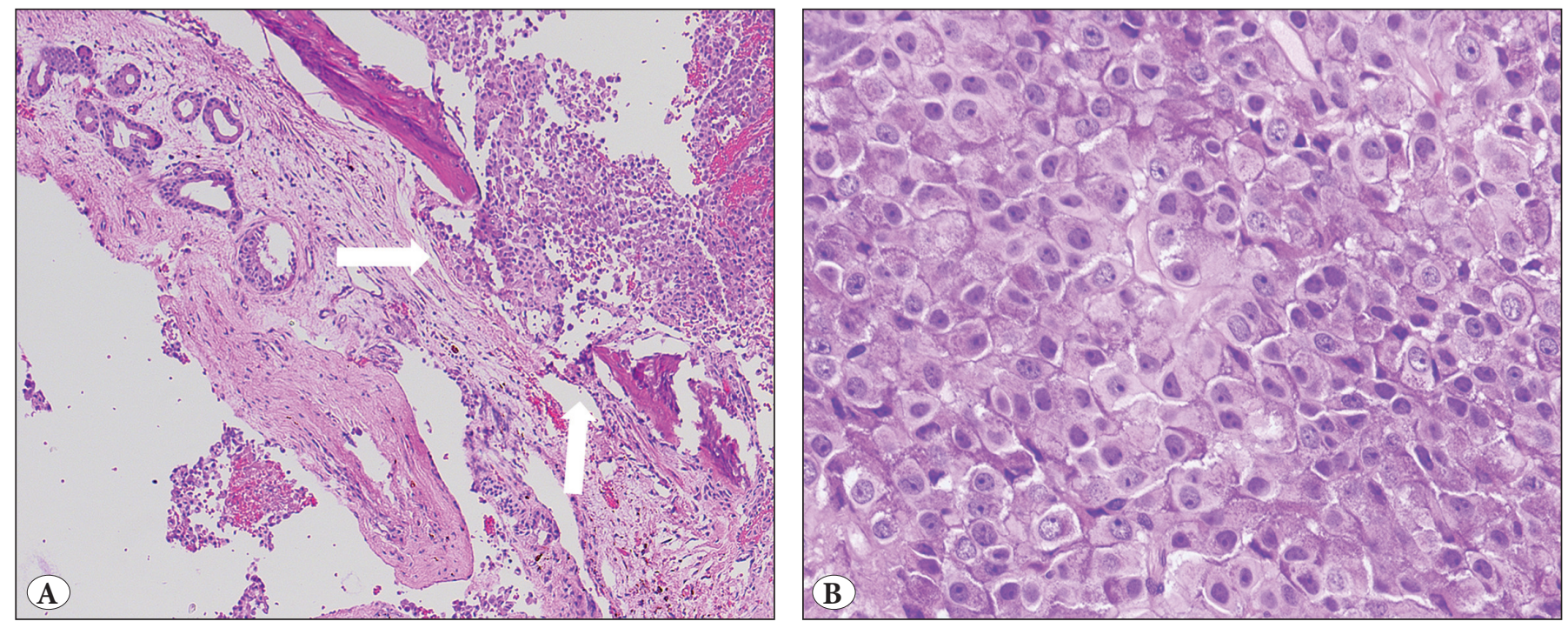

Figure 6: Crooke cell adenoma. A) These rare tumors are often invasive pituitary adenomas (arrows) and B) display a predominant Crooke's hyaline change.

plurihormonal Pit-1 lineage adenomas), unusual plurihormonal adenomas, and thyrotroph adenomas can all result in TSH excess. TSH expressing adenomas are characteristically invasive fibrotic macroadenomas that present with mass effect and central hyperthyroidism (7376). Not surprisingly, residual/recurrent disease is frequent; of additional note, recurrences do not seem to correlated with the Ki67 labeling index that reflects proliferation (73). Fortunately, for tumours that are not curable with surgery, somatostatin analogues have proven to be effective in the management of hyperthyroidism and in some cases treatment with these agents also results in tumour shrinkage $(76,77)$.

\section{F. THYROTROPH HYPERPLASIA MIMICKING A PITUITARY ADENOMA: AN EXAMPLE OF A PREVENTABLE CLINICAL ERROR}

Questions for the Clinician: Does the patient with a diffusely enlarged pituitary have baseline pituitary function tests that rule out primary hypothyroidism? 
Clinical Relevance: Thyrotroph hyperplasia resolves with treatment of primary hypothyroidism

Unfortunately, and as previously reported (78-80), we have seen surgically resected pituitaries containing thyrotroph hyperplasia with or without lactotroph hyperplasia due to longstanding primary hypothyroidism. Diffuse pituitary enlargement (with or without mass effect) associated with mild hyperprolactinemia (due to TRH stimulation of lactotrophs or stalk effect) may be misdiagnosed as a prolactinoma $(78,79)$. This underscores the relevance of complete baseline anterior pituitary function assessment for all patients with a suspected pituitary macroadenoma. It is the clinician and not the pathologist who should make the diagnosis of hypothyroidism. Radiology can be helpful as well, since hyperplastic pituitaries show symmetrical enlargement with no localized gadolinium enhancement that distinguishes non-tumorous from adenomatous adenohypophysis. With appropriate treatment of the primary hypothyroidism, thyrotroph and lactotroph hyperplasia regress, requiring months to up to two years, but ultimately magnetic resonance imaging of the pituitary returns to normal $(81,82)$.

\section{G. PITUITARY CARCINOMA}

Questions for the Pathologist and the Clinician: What defines a pituitary carcinoma? Where does an atypical adenoma stand in this spectrum? What are the potential treatments for pituitary carcinoma?

There are several factors that support the belief that pituitary carcinomas arise mainly from transformed adenomas, namely, the initial presentation of pituitary carcinomas as aggressive adenomas, the generally long time required for the progression to carcinoma development, and the progressive accumulation of genetic abnormalities (83). However, it is important to emphasize that the diagnosis of pituitary carcinoma is not based on morphologic criteria, instead it is established by the identification of metastatic disease (Figure 7), which may be cerebrospinal or systemic (84).

The categorization of an adenoma as "atypical" does not predict malignant behaviour. Furthermore, pituitary adenomas with invasive growth do not necessarily exhibit a high proliferation rate as determined by the Ki67 labeling index. Therefore, an approach that integrates accurate subtyping of the pituitary adenoma, biomarkers such as Ki67 and p53, intraoperative and radiologic findings of invasion, and response to therapy is warranted. Trouillas et al. (85) have shown that pituitary adenomas that are classified based on clinicopathologic features as "invasive and proliferative" have a probability of tumour persistence that is 25 times higher than "non-invasive and non-proliferative" tumours. Furthermore, the probability of recurrence was 12 times higher in the "invasive and proliferative group".

Unfortunately, effective therapies for pituitary carcinomas and recurrent invasive macroadenomas resistant to conventional modalities are still lacking. However, temozolomide, an $\mathrm{O}^{6}$ and $\mathrm{N}^{7}$ guanine-alkylating agent approved for the treatment of glioblastomas and anaplastic astrocyomas (86), has emerged as a therapeutic option in those settings. It is unclear which individuals are most likely to benefit from the use of temozolomide but given its mechanism of action, it would seem logical to assume that patients with a faulty DNA repair enzymes would be better candidates for treatment. Nevertheless, studies evaluating $\mathrm{O}^{6}$-alkylguanine DNA alkyltransferase (MGMT) expression have yielded inconsistent results. Perhaps, rather than the qualitative observation of low or high MGMT expression, a more quantitative approach will provide more reliable information; in this regard, a recent study has shown that MGMT staining below $50 \%$ is associated with a high likelihood of treatment response (87).

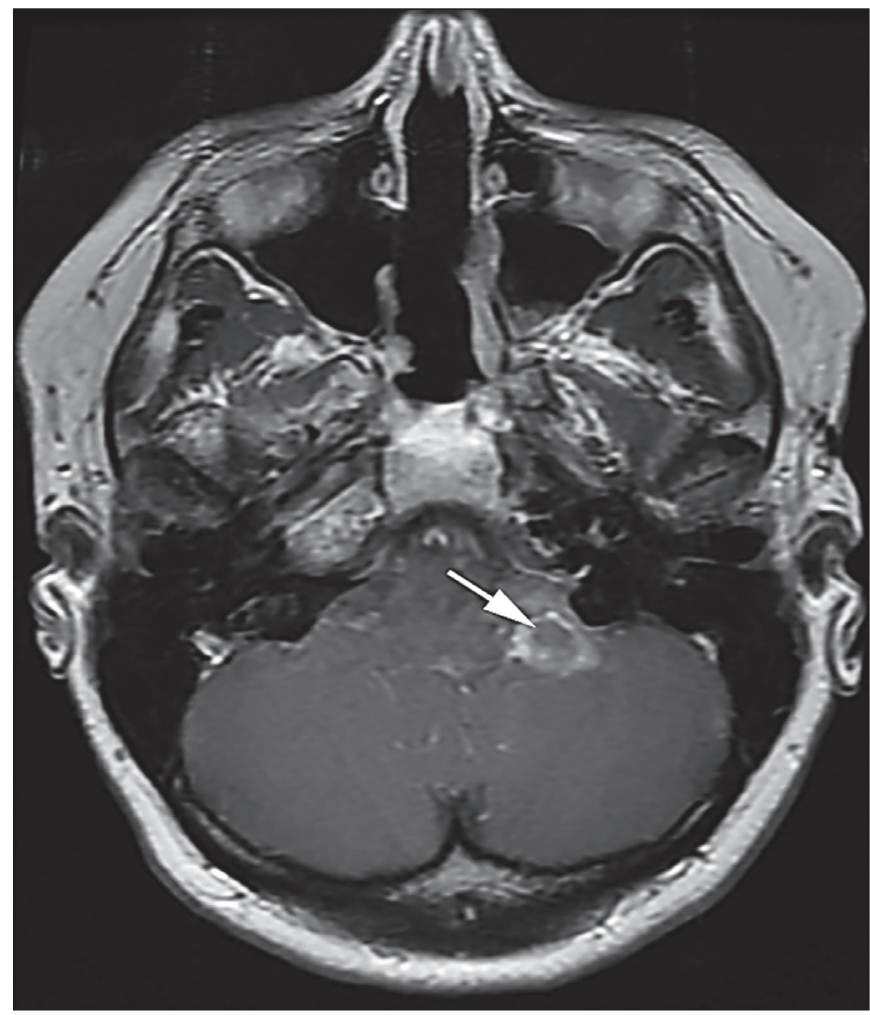

Figure 7: Pituitary carcinoma. The magnetic resonance image shows a metastatic focus in the cerebellopontine angle identified 5 years after pituitary adenoma diagnosis. 


\section{CONCLUSION}

Accurate subtyping of pituitary adenomas allows for diagnostic confirmation of clinically suspected disease conditions. Furthermore, it allows for the identification of patients that may be at higher risk of recurrent disease and in some circumstances may dictate therapeutic responses. Pathologists play an essential role in the multidisciplinary endocrine oncology team by accurately classifying pituitary tumours as standard practice.

\section{CONFLICT OF INTEREST}

The authors have declared no conflict of interest.

\section{REFERENCES}

1. Al-Brahim NY, Asa SL. My approach to pathology of the pituitary gland. J Clin Pathol. 2006;59:1245-53.

2. Asa SL, Ezzat S. The pathogenesis of pituitary tumors. Annu Rev Pathol. 2009;4:97-126.

3. Asa SL. Tumors of the pituitary gland. Washington, DC:Armed Forces Institute of Pathology. 2011

4. Mete O, Ezzat S, Asa SL. Biomarkers of aggressive pituitary adenomas. J Mol Endocrinol. 2012;49:R69-78.

5. Mete O, Asa SL. Clinicopathological correlations in pituitary adenomas. Brain Pathol. 2012;22:443-53.

6. Nose V, Ezzat S, Horvath E, Kovacs K, Laws ER, Lloyd R, Lopes $\mathrm{MB}$, Asa SL. Protocol for the examination of specimens from patients with primary pituitary tumors. Arch Pathol Lab Med. 2011;135:640-6.

7. Yamada S, Ohyama K, Taguchi M, Takeshita A, Morita K, Takano K, Sano T. A study of the correlation between morphological findings and biological activities in clinically nonfunctioning pituitary adenomas. Neurosurgery. 2007;61:580-4; discussion 584-5.

8. Erickson D, Scheithauer B, Atkinson J, Horvath E, Kovacs K, Lloyd RV, Young WF Jr. Silent subtype 3 pituitary adenoma: A clinicopathologic analysis of the Mayo Clinic experience. Clin Endocrinol (Oxf). 2009;71:92-9.

9. Nishioka $\mathrm{H}$, Inoshita $\mathrm{N}$, Mete $\mathrm{O}$, Asa S, Hayashi K, Takeshita A, Fukuhara N, Yamaguchi-Okada M, Takeuchi Y, Yamada S. The crucial role of transcription factors in the accurate diagnosis of nonfunctioning pituitary adenomas. Submitted.

10. Balogun JA, Monsalves E, Juraschka K, Parvez K, Kucharczyk W, Mete O, Gentili F, Zadeh G. Null cell adenomas of the pituitary gland: An institutional review of their clinical imaging and behavioral characteristics. Endocr Pathol. 2015;26:63-70.

11. Horvath E, Kovacs K, Killinger DW, Smyth HS, Platts ME, Singer W. Silent corticotropic adenomas of the human pituitary gland: A histologic, immunocytologic, and ultrastructural study. Am J Pathol. 1980;98:617-38.

12. Scheithauer BW, Jaap AJ, Horvath E, Kovacs K, Lloyd RV, Meyer FB, Laws ER Jr., Young WF Jr. Clinically silent corticotroph tumors of the pituitary gland. Neurosurgery. 2000;47:723-9; discussion 729-30.
13. Cooper O, Ben-Shlomo A, Bonert V, Bannykh S, Mirocha J, Melmed S. Silent corticogonadotroph adenomas: Clinical and cellular characteristics and long-term outcomes. Horm Cancer. 2010;1:80-92.

14. Alahmadi H, Lee D, Wilson JR, Hayhurst C, Mete O, Gentili F, Asa SL, Zadeh G. Clinical features of silent corticotroph adenomas. Acta Neurochir (Wien). 2012;154:1493-8.

15. Cho HY, Cho SW, Kim SW, Shin CS, Park KS, Kim SY. Silent corticotroph adenomas have unique recurrence characteristics compared with other nonfunctioning pituitary adenomas. Clin Endocrinol (Oxf). 2010;72:648-53.

16. Mete O, Hayhurst C, Alahmadi H, Monsalves E, Gucer H, Gentili F, Ezzat S, Asa SL, Zadeh G. The role of mediators of cell invasiveness, motility, and migration in the pathogenesis of silent corticotroph adenomas. Endocr Pathol. 2013;24:191-8.

17. Asa SL. Practical pituitary pathology: What does the pathologist need to know? Arch Pathol Lab Med. 2008;132:1231-40.

18. Mete O, Asa SL. Therapeutic implications of accurate classification of pituitary adenomas.Semin Diagn Pathol. 2013;30:158-64.

19. Felix IA, Horvath E, Kovacs K. Massive Crooke's hyalinization in corticotroph cell adenomas of the human pituitary. A histological, immunocytological, and electron microscopic study of three cases. Acta Neurochir (Wien). 1981;58:235-43.

20. George DH, Scheithauer BW, Kovacs K, Horvath E, Young WF Jr, Lloyd RV, Meyer FB. Crooke's cell adenoma of the pituitary: An aggressive variant of corticotroph adenoma. Am J Surg Pathol. 2003;27:1330-6.

21. Horvath E, Kovacs K, Smyth HS, Killinger DW, Scheithauer BW, Randall R, Laws ER Jr, Singer W. A novel type of pituitary adenoma: Morphological features and clinical correlations. J Clin Endocrinol Metab. 1988;66:1111-8.

22. Horvath E, Kovacs K, Smyth HS, Cusimano M, Singer W. Silent adenoma subtype 3 of the pituitary--immunohistochemical and ultrastructural classification: A review of 29 cases. Ultrastruct Pathol. 2005;29:511-24.

23. Mete O, Gomez-Hernazdez K, Ezzat S, Asa S. Pituitary Silent Subtype III Adenomas are not Always Silent and Represent Pit1 Lineage Adenomas. Modern Pathology. 2015;28(S2):138A. (Abstract no: 540)

24. Cheng S, Al-Agha R, Araujo PB, Serri O, S LA, Ezzat S. Metabolic glucose status and pituitary pathology portend therapeutic outcomes in acromegaly. PLoS One. 2013;8:e73543.

25. Andreeva M, Georgiev T, Bosadjieva E, Karagiosov L, Karagiosov K, Tomova A, Matrosov P, Kirilov G, Diankov L, Christova T. A clinicomorphological study of pituitary tumors associated with the clinical syndrome of acromegaly. Exp Clin Endocrinol. 1991;98:223-7.

26. Maheshwari HG, Prezant TR, Herman-Bonert V, Shahinian H, Kovacs K, Melmed S. Long-acting peptidomimergic control of gigantism caused by pituitary acidophilic stem cell adenoma. J Clin Endocrinol Metab. 2000;85:3409-16.

27. Horvath E, Kovacs K, Singer W, Smyth HS, Killinger DW, Erzin C, Weiss MH. Acidophil stem cell adenoma of the human pituitary: Clinicopathologic analysis of 15 cases. Cancer. 1981;47:761-71. 
28. Lim JS, Ku CR, Lee MK, Kim TS, Kim SH, Lee EJ. A case of fugitive acromegaly, initially presented as invasive prolactinoma. Endocrine. 2010;38:1-5.

29. Mete O, Gomez-Hernandez K, Ezzat S, Asa S. Clinicopathologic Features of Pituitary Acidophil Stem Cell Adenomas. Modern Pathology. 2015;28(S2):138A. (Abstract no: 539).

30. Molitch ME. Pharmacologic resistance in prolactinoma patients. Pituitary. 2005;8:43-52.

31. Vroonen L, Jaffrain-Rea ML, Petrossians P, Tamagno G, Chanson P, Vilar L, Borson-Chazot F, Naves LA, Brue T, Gatta B, Delemer B, Ciccarelli E, Beck-Peccoz P, Caron P, Daly AF, Beckers A. Prolactinomas resistant to standard doses of cabergoline: A multicenter study of 92 patients. Eur J Endocrinol. 2012;167:65162.

32. Brue T, Pellegrini I, Priou A, Morange I, Jaquet P. Prolactinomas and resistance to dopamine agonists. Horm Res. 1992;38:84-9.

33. Huang C, Ezzat S, Asa SL, Hamilton J. Dopaminergic resistant prolactinomas in the peripubertal population. J Pediatr Endocrinol Metab. 2006;19:951-3.

34. Asa SL, Kovacs K, Horvath E, Singer W, Smyth HS. Hormone secretion in vitro by plurihormonal pituitary adenomas of the acidophil cell line. J Clin Endocrinol Metab. 1992;75:68-75.

35. Horvath E, Kovacs K, Singer W, Ezrin C, Kerenyi NA. Acidophil stem cell adenoma of the human pituitary. Arch Pathol Lab Med. 1977;101:594-9.

36. Trouillas J, Labat-Moleur F, Sturm N, Kujas M, Heymann MF, Figarella-Branger D, Patey M, Mazucca M, Decullier E, Verges B, Chabre O, Calender A, Groupe d'etudes des Tumeurs E. Pituitary tumors and hyperplasia in multiple endocrine neoplasia type 1 syndrome (MEN1): A case-control study in a series of 77 patients versus 2509 non-MEN1 patients. Am J Surg Pathol. 2008;32:53443.

37. Verges B, Boureille F, Goudet P, Murat A, Beckers A, Sassolas G, Cougard P, Chambe B, Montvernay C, Calender A. Pituitary disease in MEN type 1 (MEN1): Data from the France-Belgium MEN1 multicenter study. J Clin Endocrinol Metab. 2002;87:45765.

38. Salenave S, Ancelle D, Bahougne T, Raverot G, Kamenicky P, Bouligand J, Guiochon-Mantel A, Linglart A, Souchon PF, Nicolino M, Young J, Borson-Chazot F, Delemer B, Chanson P. Macroprolactinomas in children and adolescents: Factors associated with the response to treatment in 77 patients. J Clin Endocrinol Metab. 2015;100:1177-86.

39. Ezzat S, Kontogeorgos G, Redelmeier DA, Horvath E, Harris AG, Kovacs K. In vivo responsiveness of morphological variants of growth hormone-producing pituitary adenomas to octreotide. Eur J Endocrinol. 1995;133:686-90

40. Bhayana S, Booth GL, Asa SL, Kovacs K, Ezzat S. The implication of somatotroph adenoma phenotype to somatostatin analog responsiveness in acromegaly. J Clin Endocrinol Metab. 2005;90:6290-5.

41. Bakhtiar Y, Hirano H, Arita K, Yunoue S, Fujio S, Tominaga A, Sakoguchi T, Sugiyama K, Kurisu K, Yasufuku-Takano J, Takano K. Relationship between cytokeratin staining patterns and clinico-pathological features in somatotropinomae. J Clin Endocrinol Metab. 2005;90:6290-5.
42. Fougner SL, Casar-Borota O, Heck A, Berg JP, Bollerslev J. Adenoma granulation pattern correlates with clinical variables and effect of somatostatin analogue treatment in a large series of patients with acromegaly. Clin Endocrinol (Oxf). 2012;76:96102 .

43. Mazal PR, Czech T, Sedivy R, Aichholzer M, Wanschitz J, Klupp N, Budka H. Prognostic relevance of intracytoplasmic cytokeratin pattern, hormone expression profile, and cell proliferation in pituitary adenomas of akromegalic patients. Clin Neuropathol. 2001;20:163-71

44. Obari A, Sano T, Ohyama K, Kudo E, Qian ZR, Yoneda A, Rayhan N, Mustafizur Rahman M, Yamada S. Clinicopathological features of growth hormone-producing pituitary adenomas: Difference among various types defined by cytokeratin distribution pattern including a transitional form. Endocr Pathol. 2008;19:82-91.

45. Larkin S, Reddy R, Karavitaki N, Cudlip S, Wass J, Ansorge O. Granulation pattern, but not GSP or GHR mutation, is associated with clinical characteristics in somatostatin-naive patients with somatotroph adenomas. Eur J Endocrinol. 2013;168:491-9.

46. Kato M, Inoshita N, Sugiyama T, Tani Y, Shichiri M, Sano T, Yamada S, Hirata Y. Differential expression of genes related to drug responsiveness between sparsely and densely granulated somatotroph adenomas. Endocr J. 2012;59:221-8.

47. Mayr B, Buslei R, Theodoropoulou M, Stalla GK, Buchfelder M, Schofl C. Molecular and functional properties of densely and sparsely granulated GH-producing pituitary adenomas. Eur J Endocrinol. 2013;169:391-400.

48. Spada A, Arosio M, Bochicchio D, Bazzoni N, Vallar L, Bassetti M, Faglia G. Clinical, biochemical, and morphological correlates in patients bearing growth hormone-secreting pituitary tumors with or without constitutively active adenylyl cyclase. J Clin Endocrinol Metab. 1990;71:1421-6.

49. Freda PU, Chung WK, Matsuoka N, Walsh JE, Kanibir MN, Kleinman G, Wang Y, Bruce JN, Post KD. Analysis of GNAS mutations in 60 growth hormone secreting pituitary tumors: Correlation with clinical and pathological characteristics and surgical outcome based on highly sensitive GH and IGF-I criteria for remission. Pituitary. 2007;10:275-82.

50. Leontiou CA, Gueorguiev M, van der Spuy J, Quinton R, Lolli F, Hassan S, Chahal HS, Igreja SC, Jordan S, Rowe J, Stolbrink M, Christian HC, Wray J, Bishop-Bailey D, Berney DM, Wass JA, Popovic V, Ribeiro-Oliveira A, Jr., Gadelha MR, Monson JP, Akker SA, Davis JR, Clayton RN, Yoshimoto K, Iwata T, Matsuno A, Eguchi K, Musat M, Flanagan D, Peters G, Bolger GB, Chapple JP, Frohman LA, Grossman AB, Korbonits M. The role of the aryl hydrocarbon receptor-interacting protein gene in familial and sporadic pituitary adenomas.J Clin Endocrinol Metab. 2008;93:2390-401. 
51. Daly AF, Tichomirowa MA, Petrossians P, Heliovaara E, JaffrainRea ML, Barlier A, Naves LA, Ebeling T, Karhu A, Raappana A, Cazabat L, De Menis E, Montanana CF, Raverot G, Weil RJ, Sane T, Maiter D, Neggers S, Yaneva M, Tabarin A, Verrua E, Eloranta E, Murat A, Vierimaa O, Salmela PI, Emy P, Toledo RA, Sabate MI, Villa C, Popelier M, Salvatori R, Jennings J, Longas AF, Labarta Aizpun JI, Georgitsi M, Paschke R, Ronchi C, Valimaki M, Saloranta C, De Herder W, Cozzi R, Guitelman M, Magri F, Lagonigro MS, Halaby G, Corman V, Hagelstein MT, Vanbellinghen JF, Barra GB, Gimenez-Roqueplo AP, Cameron FJ, Borson-Chazot F, Holdaway I, Toledo SP, Stalla GK, Spada A, Zacharieva S, Bertherat J, Brue T, Bours V, Chanson P, Aaltonen LA, Beckers A. Clinical characteristics and therapeutic responses in patients with germ-line AIP mutations and pituitary adenomas: An international collaborative study. J Clin Endocrinol Metab. 2010;95:E373-83.

52. Denes J, Kasuki L, Trivellin G, Colli LM, Takiya CM, Stiles CE, Barry S, de Castro M, Gadelha MR, Korbonits M. Regulation of aryl hydrocarbon receptor interacting protein (AIP) protein expression by MiR-34a in sporadic somatotropinomas. PLoS One. 2015;10:e0117107.

53. Horvath E, Kovacs K, Killinger DW, Smyth HS, Weiss MH, Ezrin C. Mammosomatotroph cell adenoma of the human pituitary: A morphologic entity. Virchows Arch A Pathol Anat Histopathol. 1983;398:277-89.

54. Robert F, Pelletier G, Serri O, Hardy J. Mixed growth hormone and prolactin-secreting human pituitary adenomas: A pathologic, immunocytochemical, ultrastructural, and immunoelectron microscopic study. Hum Pathol. 1988;19:1327-34.

55. Sherlock M, Fernandez-Rodriguez E, Alonso AA, Reulen RC, Ayuk J, Clayton RN, Holder G, Sheppard MC, Bates A, Stewart PM. Medical therapy in patients with acromegaly: Predictors of response and comparison of efficacy of dopamine agonists and somatostatin analogues. J Clin Endocrinol Metab. 2009;94:125563.

56. Felix IA, Horvath E, Kovacs K, Smyth HS, Killinger DW, Vale J. Mammosomatotroph adenoma of the pituitary associated with gigantism and hyperprolactinemia. A morphological study including immunoelectron microscopy. Acta Neuropathol. 1986;71:76-82.

57. Dubuis JM, Deal CL, Drews RT, Goodyer CG, Lagace G, Asa SL, Van Vliet G, Collu R. Mammosomatotroph adenoma causing gigantism in an 8-year old boy: A possible pathogenetic mechanism. Clin Endocrinol (Oxf). 1995;42:539-49.

58. Pack SD, Kirschner LS, Pak E, Zhuang Z, Carney JA, Stratakis CA. Genetic and histologic studies of somatomammotropic pituitary tumors in patients with the "complex of spotty skin pigmentation, myxomas, endocrine overactivity and schwannomas" (Carney complex). J Clin Endocrinol Metab. 2000;85:3860-5.

59. Kurtkaya-Yapicier O, Scheithauer BW, Carney JA, Kovacs K, Horvath E, Stratakis CA, Vidal S, Vella A, Young WF, Jr., Atkinson JL, Lloyd RV, Kontogeorgos G: Pituitary adenoma in Carney complex: An immunohistochemical, ultrastructural, and immunoelectron microscopic study. Ultrastruct Pathol. 2002;26:345-53.
60. Boikos SA, Stratakis CA. Pituitary pathology in patients with Carney Complex: Growth-hormone producing hyperplasia or tumors and their association with other abnormalities. Pituitary. 2006;9:203-9.

61. Kovacs K, Horvath E, Thorner MO, Rogol AD. Mammosomatotroph hyperplasia associated with acromegaly and hyperprolactinemia in a patient with the McCune-Albright syndrome. A histologic, immunocytologic and ultrastructural study of the surgically-removed adenohypophysis. Virchows Arch A Pathol Anat Histopathol. 1984;403:77-86.

62. Vortmeyer AO, Glasker S, Mehta GU, Abu-Asab MS, Smith JH, Zhuang Z, Collins MT, Oldfield EH. Somatic GNAS mutation causes widespread and diffuse pituitary disease in acromegalic patients with McCune-Albright syndrome. J Clin Endocrinol Metab. 2012;97:2404-13.

63. Moran A, Asa SL, Kovacs K, Horvath E, Singer W, Sagman U, Reubi JC, Wilson CB, Larson R, Pescovitz OH. Gigantism due to pituitary mammosomatotroph hyperplasia. N Engl J Med. 1990;323:322-7.

64. Glasker S, Vortmeyer AO, Lafferty AR, Hofman PL, Li J, Weil RJ, Zhuang Z, Oldfield EH. Hereditary pituitary hyperplasia with infantile gigantism. J Clin Endocrinol Metab. 2011;96:E2078-87.

65. Puchner MJ, Ludecke DK, Saeger W, Riedel M, Asa SL. Gangliocytomas of the sellar region--a review. Exp Clin Endocrinol Diabetes. 1995;103:129-49.

66. Sano T, Asa SL, Kovacs K. Growth hormone-releasing hormoneproducing tumors: Clinical, biochemical, and morphological manifestations. Endocr Rev. 1988;9:357-73.

67. Garby L, Caron P, Claustrat F, Chanson P, Tabarin A, Rohmer V, Arnault G, Bonnet F, Chabre O, Christin-Maitre S, du-Boullay H, Murat A, Nakib I, Sadoul JL, Sassolas G, Claustrat B, Raverot G, Borson-Chazot F, Group GTE. Clinical characteristics and outcome of acromegaly induced by ectopic secretion of growth hormone-releasing hormone (GHRH): A French nationwide series of 21 cases. J Clin Endocrinol Metab. 2012;97:2093-104.

68. Bochicchio D, Losa M, Buchfelder M. Factors influencing the immediate and late outcome of Cushing's disease treated by transsphenoidal surgery: A retrospective study by the European Cushing's Disease Survey Group. J Clin Endocrinol Metab. 1995;80:3114-20.

69. Chee GH, Mathias DB, James RA, Kendall-Taylor P. Transsphenoidal pituitary surgery in Cushing's disease: Can we predict outcome? Clin Endocrinol (Oxf). 2001;54:617-26.

70. Carey RM, Varma SK, Drake CR, Jr., Thorner MO, Kovacs K, Rivier J, Vale W. Ectopic secretion of corticotropin-releasing factor as a cause of Cushing's syndrome. A clinical, morphologic, and biochemical study. N Engl J Med. 1984;311:13-20.

71. McNicol AM. Patterns of corticotropic cells in the adult human pituitary in Cushing's disease. Diagn Histopathol. 1981;4:335-41.

72. Kovacs K, Horvath E, Coire C, Cusimano M, Smyth H, Scheithauer BW, Lloyd RV. Pituitary corticotroph hyperplasia preceding adenoma in a patient with Nelson's syndrome. Clin Neuropathol. 2006;25:74-80. 
73. Kirkman MA, Jaunmuktane Z, Brandner S, Khan AA, Powell M, Baldeweg SE. Active and silent thyroid-stimulating hormoneexpressing pituitary adenomas: Presenting symptoms, treatment, outcomes, and recurrence. World Neurosurg. 2014;82:1224-31.

74. Clarke MJ, Erickson D, Castro MR, Atkinson JL. Thyroidstimulating hormone pituitary adenomas. J Neurosurg. 2008;109:17-22.

75. Brucker-Davis F, Oldfield EH, Skarulis MC, Doppman JL, Weintraub BD. Thyrotropin-secreting pituitary tumors: Diagnostic criteria, thyroid hormone sensitivity, and treatment outcome in 25 patients followed at the National Institutes of Health.J Clin Endocrinol Metab. 1999;84:476-86.

76. Socin HV, Chanson P, Delemer B, Tabarin A, Rohmer V, Mockel J, Stevenaert A, Beckers A. The changing spectrum of TSHsecreting pituitary adenomas: Diagnosis and management in 43 patients. Eur J Endocrinol. 2003;148:433-42.

77. Beck-Peccoz P, Persani L, Mannavola D, Campi I. Pituitary tumours: TSH-secreting adenomas. Best Pract Res Clin Endocrinol Metab. 2009;23:597-606.

78. Khalil A, Kovacs K, Sima AA, Burrow GN, Horvath E. Pituitary thyrotroph hyperplasia mimicking prolactin-secreting adenoma. J Endocrinol Invest. 1984;7:399-404.

79. Pioro EP, Scheithauer BW, Laws ER Jr, Randall RV, Kovacs KT, Horvath E. Combined thyrotroph and lactotroph cell hyperplasia simulating prolactin-secreting pituitary adenoma in longstanding primary hypothyroidism. Surg Neurol. 1988;29:218-26.

80. Alkhani AM, Cusimano M, Kovacs K, Bilbao JM, Horvath E, Singer W. Cytology of pituitary thyrotroph hyperplasia in protracted primary hypothyroidism. Pituitary. 1999;1:291-5.
81. Passeri E, Tufano A, Locatelli M, Lania AG, Ambrosi B, Corbetta S. Large pituitary hyperplasia in severe primary hypothyroidism. J Clin Endocrinol Metab. 2011;96:22-3.

82. Johnston PC, Ellis PK, Hunter SJ. Thyrotroph hyperplasia. Postgrad Med J. 2014;90:56-7.

83. Kaltsas GA, Nomikos P, Kontogeorgos G, Buchfelder M, Grossman AB. Clinical review: Diagnosis and management of pituitary carcinomas. J Clin Endocrinol Metab. 2005;90:3089-99.

84. DeLellis RA. Pathology and genetics of tumours of endocrine organs. Lyon:IARC Press.2004.

85. Trouillas J, Roy P, Sturm N, Dantony E, Cortet-Rudelli C, Viennet G, Bonneville JF, Assaker R, Auger C, Brue T, Cornelius A, Dufour H, Jouanneau E, Francois P, Galland F, Mougel F, Chapuis F, Villeneuve L, Maurage CA, Figarella-Branger D, Raverot G, members of $\mathrm{H}$, Barlier A, Bernier M, Bonnet F, Borson-Chazot F, Brassier G, Caulet-Maugendre S, Chabre O, Chanson P, Cottier JF, Delemer B, Delgrange E, Di Tommaso L, Eimer S, Gaillard S, Jan M, Girard JJ, Lapras V, Loiseau H, Passagia JG, Patey M, Penfornis A, Poirier JY, Perrin G, Tabarin A. A new prognostic clinicopathological classification of pituitary adenomas: A multicentric case-control study of 410 patients with 8 years postoperative follow-up. Acta Neuropathol. 2013;126:123-35.

86. FDA. Temozolomide FDA label. 2011

87. Bengtsson D, Schroder HD, Andersen M, Maiter D, Berinder K, Feldt Rasmussen U, Rasmussen AK, Johannsson G, Hoybye C, van der Lely AJ, Petersson M, Ragnarsson O, Burman P. Longterm outcome and MGMT as a predictive marker in 24 patients with atypical pituitary adenomas and pituitary carcinomas given treatment with temozolomide. J Clin Endocrinol Metab. 2015;100:1689-98 